\title{
BRITISH AND AMERICAN TRADE UNIONISM
}

\author{
Bx William English Walling, \\ New York City.
}

Friends and enemies of trade unionism in this country have alike assumed that the unions of Great Britain are a more highly developed form of labor organization than the unions of the United States. Undoubtedly any scientific or historical view of the labor movement in the United States must be based on a study of the British unions. There is no question that the union idea came to us not from the Continent of Europe which is furnishrng us a large majority of our working people to-day, but from Great Britain which gave us our people and our institutions over a hundred years ago. Nor is there any doubt that the labor movement reached a very highly developed form in Great Britain some years ago before it had attained any considerable strength here or even before it had spread to any considerable proportion of our trades and industries.

But is it not true that the American unions are developing toward the British type, but quite the reverse. Just as America leads Great Britain in industrial development, in the enterprise and aggressiveness of her employers, so she is beginning to lead Great Britain in the intelligence and thoroughness of her organization of labor.

What is most important in the study of the labor movement of the United States to-day is not the similarity, but the contrast between the British and the American unions. The failure to see that the British form of trade union has not only ceased to advance in the United States, but is decaying both relatively when compared with the newer types of unions and also absolutely furnishes the only adequate explanation of a series of the most radical misinterpretations of the American labor movement that seems to have no end. What are the features of the trade unions of Great Britain most vented in public discussions of the labor question to-day? [72I] 
Large accumulated funds and insurance benefits. The effort to preserve the proportion of intelligent and skilled workers in the industry against raw and inexperienced recruits. The general absence of closed shop agreements. These features are paraded by the friends of labor in this country as evidence of the merits of trade unionism where it has reached its most developed form. On the other hand, the equally British policies of restriction of apprentices, opposition to the subdivision of labor, restriction of output (to afford work for all the members of the union), indirect restrictions of machinery (through the demand that wages paid for the workers on new machines be so much increased that the introduction of the machines is automatically limited), are held up by the enemies of the unions here as the horrible example of what is in certain store in the future for the United States. Both enemies and friends have failed to see that the two movements having the same name and the same country of origin have come to rest on principles as widely divergent as the political and economic institutions of Great Britain and the United States. Both movements are to be sure primarily economic rather than political in their character, both are built on an organization of labor by trade or industry rather than an organization by locality, both are seeking first of all more wages and shorter hours, and both rely largely on the strike. But here the similarity in essentials seems to cease. The two movements differ in the origin of their power, in the form of their organization, in their tactics and in their ultimate aim.

In claiming that American unions are developing toward the British type, the friends of unionism in this country in so far as they have any influence at all on a movement that is so deeply economic and unconscious in its character, pledge it to the narrow sectional or "trade" policy of its British prototype. The fundamental principle that underlies every one of the policies that characterize these unions, whether good or bad, is the effort to gain and maintain a monopoly of the skilled workers in a given industry or trade.

The unions of Great Britain are, with relatively few exceptions, "trade" unions in a distinct narrow sense. They are founded not so much on the principles of the organization of employees against employers as on that of the organization of a certain grade of labor against all other grades. The principle is one of monopoly. Hon. 
Carroll D. Wright defends this monopoly as "the vested interest" of the worker in that trade in which he has put so many years of his life. And from this point of view alone can the monopoly be defended. But it must be remembered that the consumer, that is to say the community, rather than the employer must usually pay the bill, and it will be conceded that if any other method can be arrived at by which the worker's condition can be protected without causing any monopoly, without raising prices to the consumer, and without excluding the unskilled laborers who are constantly clamoring for work and to whom the community certainly owes an equal debt, it would be better for the skilled worker, the unskilled worker, the consumer and the whole community alike.

The attempted monopoly of skill fostered by the British unions has been the essence of their being. By the direct restriction of apprentices in the trade, by refusing to allow them to enter the union and benefit from its advantages and by the opposition to the division and specialization of labor, involved in their insistence that the apprentice shall learn "all the trade," the British unions attempt to maintain a monopoly of the skilled men. This policy militates against all improvements in industry that are based on the attempt to save the labor of skilled and exceptionally intelligent and trained men by substituting men of less training and skill where this can be economically accomplished.

The British unions widely encourage the restriction of output. By restriction of output we mean an unwritten law of the working people that limits the amount of work a man should do. The fact that the unions did not invent this law, but the individual workers themselves, does not relieve them from the responsibility for its enforcement. The unwritten law can be made effective only when the employer's discipline is broken down by the counter-discipline of the union. The British unions find it a most convenient means of securing a monopoly of labor. Having secured control over the amount of work done, they attempt by doing less work to secure jobs either (I) for union men out of employment through no fault of their own, or (2) for relatively inferior union workmen. This system has also been further developed into a conscions attempt not only to secure the employment for all the union's unemployed, but (3) even for the far more momentous purpose of bringing about a scarcity of labor. As soon as this point of scarcity approaches, [723] 
the wages of labor tend to rise by the natural economic law of supply and demand, the union enforces the recognition of the conditions of the labor market and has the employer and the industry at its command.

Not only do the greater number of the British unions commonly seek a monopoly of skilled men and a monopolistic control of the amount of work to be done by these men, but they also seek to obtain a partial monopoly of the benefits of industrial progress. Those unions where machinery is being most rapidly introduced always deny that they have restricted the machine, and their denial is true if taken in a narrow sense. But they do claim that because certain industrial processes which are due to the scientific or technical advances of society at large have happened to strike their industry, they and no others should obtain a large share of the benefit of these processes. On this ground they demand, when their men are put to work on new or better machines that they should secure considerably better wages even if the work to be done is simpler in its character than what was done before. Or they restrict the number of machines at which a man is allowed to work on the ground not that the machines ought to be prohibited, but that they should not be introduced so rapidly as to throw a large number of men out of employment.

To these grounds for restriction of output, a fourth, the most dangerous of all, has recently assumed a new and threatening importance. In recent years since the complete failure of the great engineers' strike which cost the British unions such an immense sum and since the epidemic of adverse decisions in the courts have tied up union treasuries, strikes have grown more and more infrequent and unsuccessful. Notwithstanding the large accumulated funds of the unions, it has been found that the even greater financial resources of the well-organized employers' associations, backed as they have been recently by the financial community and the courts, have enabled them to hold out either until the working people were starved into submission or until new hands were trained into the industry. But the strike is not the last resource of a laboring population that cannot be physically coerced to labor. Since the strike as the chief weapon of unionism has begun to fail, the Ca Canny system has come to take its place. This term is simply the British expression for the restriction of output when socially enforced by the 
working people who call out the Scotch word "canny" to their fellow workers when they are of the opinion that these latter are working harder or faster than necessity or good policy dictates. But the term has becone more specialized recently than this definition would indicate. It has come to stand not so much for the restrictions above mentioned made for the hopeful purposes of increasing employment or creating a scarcity of labor as to those desperate reprisals of men who have been beaten in a strike and who say, "if we cannot increase the amount of our pay no power on earth can prevent us from decreasing the amount of our work." It is not an ordinary businesslike attempt to secure a monopoly, but a new form of revolt far more dangerous to industry and the employer than the strike itself.

Now, the development of the American industry and the flooding of the American labor market with cheap foreign labor has proceeded at such a pace that any and all of these restrictive poliicies are forever impossible in this country upon any such scale as they have been practised on the other side. The relative success of the British unions in securing these various monopolistic charges, as against other unorganized workmen and society at large, is due fundamentally to one fact alone, the greater importance of manual skill in British industry.

The unions of Great Britain were founded at a time when manual skill was of much greater importance than it is in Great Britain to-day. In America the denand for this sort of skill has to an even greater extent been replaced by a demand for men without any special manual skill, but with an intelligent grasp of the rudimentary principles of machinery, a ready adaptability to the ever-changing tasks of a machine age or to that great mass of unskilled work, handling of raw materials and products and other simple tasks that have also been created by the machine development.

In a former article ${ }^{1}$ on the importance of unskilled labor in the United States, we have shown the underlying economic causes of this development. It is only necessary now to point out that this economic development has been followed by corresponding changes in the form and organization of the labor unions themselves. The conclusions of the previous article were briefly that new machinery and the subdivision of labor were increasing the proportion of

1 The Annals, Vol, xxiv, page 296. 
relatively unskilled labor in all the leading industries, that the new skilled trades demand intelligence and responsibility rather than manual skill, while the new unskilled trades demand speed and nervous intensity rather than mere physical power and endurance as before. It was seen that the division of an industry into a hundred instead of half a dozen branches had forced the unions of the many trades of each industry into one new type of organization, the industrial union. It was also seen that the difficulty of bringing machinery into certain kinds of work common to all industry such as teaming and driving, machine repairing, steam engineering, firing, etc., had increased the numerical ratio of the workmen in these relatively unskilled trades and caused the formation of new trade unions extending not through one or two industries as formerly, but covering practically the whole industrial field. All of these tendencies have had their effect on the form of labor organization that has developed in the United States until it has grown into such a different thing from the unionism of Great Britain that the economics and history of trade unionism in that country have become comparatively useless for ours.

The British unions have practically failed to organize unskilled labor on any considerable scale. With a few exceptions the only methods by which the British labor movement has been able to organize the unskilled has been through the large "common labor" associations, the so-called new unionism, a form of labor organization practically unknown in the United States. Here, a better policy has brought much better results. The inter-trade "industrial unions," after organizing the skilled, have succeeded in organizing many of the unskilled trades of several industries, while the interindustrial "trade unions" have organized in some localities nearly all the workers of some trades even in industries where no unions of skilled workers have secured a foothold. Common laborers, women and newly arrived immigrants, have in this way been brought together with older and more skilled men into one organization instead of being left alone as in Great Britain to struggle along in a weak or temporary union of their own.

Of the "industrial" unions of Anerica, that of the coal miners with more than a quarter million members is by far the most important. But if we add to this membership that of other purely industrial unions, such as the butchers with 34,000 members, the 
iron and steel workers with 13,000 , the carworkers and piano workers with about 10,000 each, the paper makers with 8,800 and the potters and carriage and wagon workers with about 5,200 each, we have 87,000 in addition from seven unions alone. Other industrial unions that owe their success partly to the label are included in another reckoning below. If added to the above, we would have a total of 500,000 unionists in the industrial form of organization. Nor is this all. Those federations which are not purely local are industrial in their nature. If we were to add the industrially federated building trades of more than half a million members, our total of industrial organization would considerably exceed $1,000,000$ members. And the work of a considerable majority of the membership of most of these unions is to be classed as relatively unskilled.

The membership of the corresponding unions in Great Britain is less in some cases and in all it is more or less along trade rather than industrial lines. There are no special unions of any importance among the butchers, brewers, car workers, piano workers or carriage workers, while that among the iron and steel workers is confined largely to the smelters. Their membership is a fraction of that of the corresponding unions in the United States. The building trades, without any national central organization, are split up into numerous local groups, of which the thirty largest do not contain half of the whole. The largest of several federations of coal miners' unions still leaves a third of the unions outside, while the principal power is in the hands of at least ten different unions, besides a large number of small ones. Finally, the less skilled workers about the mines are either separately organized, even if admitted to the federation, or ignored entirely, while the miners are all relatively skilled men, since neither the machine work of our bituminous fields nor the subdivision of labor which has brought unskilled labor into the anthracite regions has yet come into use. If half a million coal miners are organized in Great Britain against half that number in the United States, the coal mining industries being about the same in both countries, it is partly because the work of each miner goes so much further here on account of the better methods of work, and because there are several hundred thousand less miners in the United States.

Another means by which American unions have organized the unskilled is through the new type of "trade" union that flourishes in 
several or all industries where workers of the trade are found. In a few years the teamsters have increased to 84,000 members, of which haif are enrolled in the Chicago unions alone. At the Chicago ratio 500,000 of the 600,000 teamsters in the United States may be considered as possible future members. In I 901 the six principal unions in this trade in Great Britain aggregated less than 25,000 members. Similarly the Stationary Engineers and Firemen's Unions, which numbered less than 5,000 in the United States a few years ago, have grown to 35,000 to-day. The five leading British organizations, though much older, had in I901 only I3,000 members and the federation embraced scarcely more than 20,000 .

American unions have also organized the workers in another capacity entirely-as consumers. In Great Britain the power of the working people as consumers to assist the working people as producers has been almost ignored. The only form of organization of consumers that has succeeded among the laboring masses there, has been the great co-operative societies. The relation, however, between these and the unions is not only very weak, but has at times even been strained. In America, on the other hand, we have the boycott in all its forms, often most effective, and above all the union label. Depending as it does on the number of "union" consumers, the American policy of organizing the great masses of unskilled labor is the foundation of its success. On the other hand, it is largely due to this union label or union button that about 400,000 American working people, largely unskilled, have been able to organize. The numerical strength of the more important of this class of organizations in 1904 is shown in the following table. A large proportion of the workers in most of these industries is relatively unskilled.

\section{Unions Which Depend on the Label.}

(The total strength of the unions in these same trades and industries in Great Britain is considerably less than 100,000, some of them having no existence there at all.)

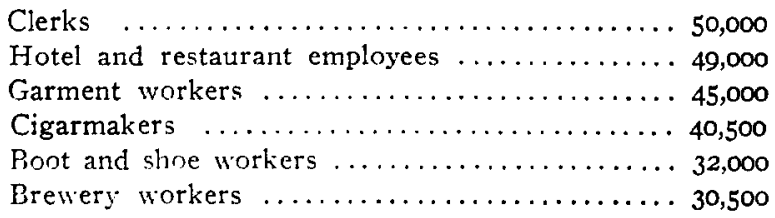

[728]. 


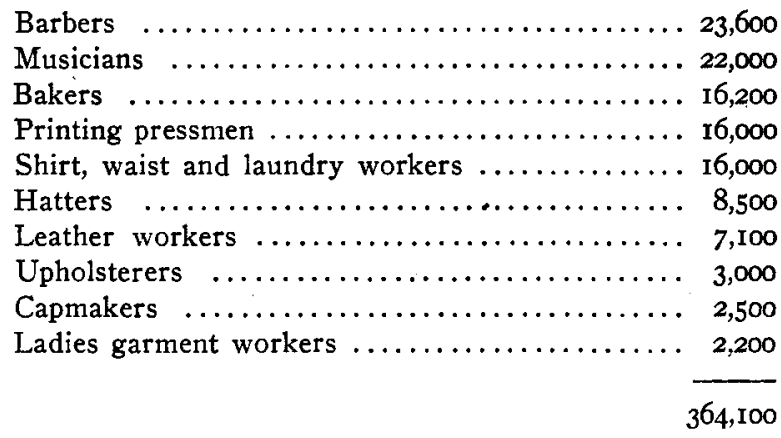

In this country we also have the federation principle developed to an extent unknown in Great Britain. Federation helps more than anything else perhaps in the organization of the unskilled. The motto of the American Federation of Labor is "educate, agitate, organize." Practically all the education in unionism, the agitation of unionism and the organization of unions accomplished in Great Britain, has been done not by any federation, but by the separate trade unions. It has therefore necessarily been along narrow lines in its principles and restricted in its application to those least in need of it. In America, speakers, organizers and financial assistance are never lacking for the new and struggling organization that has shown itself worthy of support. The organizers of the American Federation of Labor are numbered by the hundred and each year several million dollars are distributed to the weaker unions in one way or another through the national and local organizations that compose it. The federation has proven invaluable to the weaker unions in times of strikes. Not only has it made possible a far more effective financial assistance to the unions of the unskilled, but it has even brought about a good many sympathetic and even some more or less general strikes, such as those in Chicago, Kansas City, Denver and San Francisco, some of them by no means without some success.

Federation in Great Britain is, comparatively speaking, in a rudimentary stage. Hardly a fourth of the two million unionists are members through their organization of the new federation of trade unions. Only in the engineering trades, called by our workmen the iron trades, has Britain led. Here the federation includes over two hundred thousand union members. The strongest of the British 
federations are not federations in the American sense at all. They are composed not of an allied group of trades, but of many unions operating either in the same trade or the same industry and ought to be a single union. So in the place of the United Mine Workers, a typical union, Great Britain has a loose federation that includes nearly all of the unions in the mining industry. The largest federation in the textile industry is not even so much centralized. It includes only about three-quarters of the unionists in the industry.

The high degree of decentralization in the British union world appears in nearly every trade and industry. The ten largest unions among the miners, for instance, embrace scarcely half the total membership, while the twelve principal unions in the textile industry include less than half of the total membership. So it is with all the leading trades. In America two unions, one far more important than the other, include practically all of what are called the engineering trades in Great Britain, while the five largest unions there include only a minority of all the union members. In America there is one teamsters' organization. In Great Britain there are five important organizations in this field and twenty small ones. There is one organization of carpenters in the United States which has more than nine-tenths of all the union carpenters in the country, while there are three important organizations in Great Britain. In America there is one important organization of seamen, in Great Britain six. In America there is one important organization of garment workers, in Great Britain six. With the wood workers the proportion is again one to six; with the longshoremen, one to seven; with the compositors, one to five; with the boot and shoe workers, one to two; with the stationary engineers, one to five; with the plumbers, one to two; with the bakers, one to three; with the textile workers, one to twelve, etc. In fact there seems to be only one important trade or industry in Great Britain in which the forces of labor are completely unified, while there are very few cases indeed in America where they are divided. The British instance is that of the very powerful union of boilermakers. The only American trades or industries where there is a division of any consequence are the machinists, the carpenters and the painters. In each of these cases the larger organization is many-fold more important than the smaller and will undoubtedly swallow it up in the near future. In each case negotiations to this end are now in progress.

[730] 
The degree of division and subdivision of unions in British industry at times reaches a point that is most amazing. Especially is this the case in the metal trades where a great deal of hand work survives. So we find among the "principal divisions" of the metal trades in the report of the British Board of Trade some dozen classes of trade unions with more than one hundred sub-divisions. The classes are cutlery, file makers, silver bloaters, lock and hinge makers, wire workers, lock and bolt makers, bedstead workmen and anvil makers, to name only the more important. In the first class alone there are in Sheffield half a dozen large unions and twice as many small ones. So we have the table plate forgers, the saw makers, the spring knife grinders, the spring knife cutters, the Amalgamated Edge Tool Trade Society, and the table and butcher knife hafters, only to mention the more important. In all these trades in America only three unions are of importance-the machinists, the metal workers and the metal polishers, all on a national scale. There is a somewhat similar situation in the leather industry. In America there are only two unions of any consequence, the Leather Workers and the Leather Workers on Horses' Hoofs. In Great Britain there are a large number of organizations divided in half a dozen classes as tanning, currying, dressing and finishing, saddlery and harness, whips, etc.

As a consequence of the more narrow policy of the British unions towards unskilled labor, the total numerical strength in proportion to the number of persons employed in British industry is hardly as great as that of the American unions, although the former have the advantage of at least a generation in their age. The total number of unionists in America is probably not much short of 2,500,000 ; those of Great Britain are a little more than 2,000,000. But this does not tell half the story. The unions of the United States were estimated by the Industrial Commission to have had approximately 500,000 members in I892. In I90I they had already grown to $I, 400,000$. The unions of Great Britain, on the other hand, were three times as strong numerically at the former date, having a membership of $1,500,000$. In 1901 this figure had risen to nearly 2,000,ooo. While the membership of American unions increased nearly threefold in ten years, that of Great Britain increased less than oncthird. During the last year the tax paying membership of the American Federation of Labor rose by more than 200,000 members, 
while that of other organizations outside of the American Federation of Labor increased even more rapidly, so that the total increase during this rather bad year was perhaps something like a quarter of a million, according to the union showing. On the other hand, the membership of the British unions has for several years almost stood still. In fact the official reports of the Board of Trade show a slight decrease from I9OI to I902. Moreover, besides an increase of the membership of American unions in the most important industries up to or beyond the British level, with a few important exceptions this increase of membership has meant the organization of trades neglected almost entirely on the other side. While there are 45,000 clothing workers on men's garments organized in the United States, there were in the last report scarcely one-tenth as many in Great Britain. While in the hotels and restaurants, in the breweries and on the street railways, where American unions have secured from 30,000 to 50,000 members in each case respectively, there are in Great Britain only a few hundred union men.

Perhaps the attitude of the two movements towards unskilled labor is nowhere more clearly shown than in their relative success in organizing women. There are no accurate figures concerning the movement in the United States. But it can safely be estimated that more than 100,000 women are organized in this country. The figures for Great Britain are somewhat similar. There, in I90I, there were 120,000 women in the unions. But of these nearly 108,000 were in the textile industry alone which employs considerably less than half of the million women at work in factories. In this industry men and women both are very much better organized than in the United States, though it may be said in passing that the women are practically forced into the organization, as is also the case in many American unions.

Outside of the textile industry a most interesting situation develops. The total number of women organized in this field was, in I9OI, I2,I5I. The total number employed in the same field even two or three years before this was shown by the factory reports to be 619,or4, that is to say, the organization of women outside of the textile industry is almost insignificant. It is of interest to enter a little more closely into the classification of the 12,000 women who are organized. Of these, some 2,500 are in the hat and cap industry, which is pretty well unionized. Two thousand two hundred are in 
tobacco and 1,100 in potteries, which is a fair showing for these relatively small industries; that is to say, half of this small number of 12,000 employees are engaged in three industries, leaving a little more than 6,000 union women for industries and trades employing half a million. In Chicago alone, persons familiar with the union situation, estimate there are 15,000 union women at the present moment after considerable losses caused by the reaction in industry last summer and fall.

To sum up the relative numerical strength of the British union movement and its failure with a few exceptions to organize the unskilled, the following table will be useful. If in this connection it is remembered that the growth of the British unions has almost come to a standstill in recent years, the table will speak for itself.

Union Membership in Britisi Industry.

\begin{tabular}{|c|c|c|}
\hline Industry. & Total $\underset{(1898)}{\text { No. Employed }}$ & $\begin{array}{l}\text { Total No. in } \\
\text { Unions (rgor) }\end{array}$ \\
\hline Mining & 824,791 (I90I) & 505,023 \\
\hline etc. $\ldots \ldots \ldots$ & $\mathbf{I}, 325,975$ & 334,9 I 3 \\
\hline extiles $\ldots . . .$. & 763,384 & 219,256 \\
\hline Clothing ... & 351,622 & 66,291 \\
\hline
\end{tabular}

(In the textile industry young persons and children under eighteen have been deducted from the total. In the metal and clothing trades, they are included.)

It is impossible to prepare a similar table with any pretence of accuracy for the United States, but the situation can be summed up in a general way in each of the same industrial divisions. In mining the proportion organized in the United States is very similar to that in Great Britain, or if anything, slightly better, the total number in our unions reaching more than 300,000 out of a total of some 500,000 in the industry. In the metal trades the degree of organization in Great Britain is slightly better than in the United States.

The Union Membership in the Metal Trades of the United States.

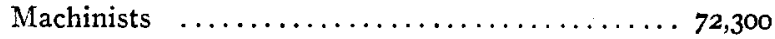

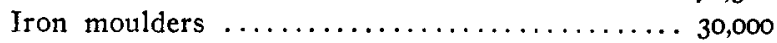

Boiler makers, ship builders, etc. . . ...... 22,400

Sheet metal workers ................ I6,300

Iron, sheet and tin workers $\ldots \ldots \ldots \ldots \ldots \ldots \ldots$ I3,500

Blacksmiths ................... 10,500

Metal workers $\ldots \ldots \ldots \ldots \ldots \ldots \ldots \ldots \ldots \ldots \ldots \ldots \ldots$ 
In I 900 the total number of persons in these industries was more than 900,000. The organization in the metal trades is therefore. somewhat better in Great Britain than in the United States. In the textiles, of course, the difference in favor of the British organizations is striking. Out of five or six hundred thousand persons employed (the Census of Occupations does not indicate the exact figures), the textile workers union here had last year a little over 10,000 members. In the clothing industry the situation is reversed. The American organizations, of which the principal are the garment workers, the boot and shoe workers, the shirt makers and the hatters, have nearly 100,000 members of the several hundred thousand in this industry. As indicated by the above figures, the proportion organized is scarcely half as great in Great Britain. The only important field besides those above mentioned, where Great Britain has an advantage, is in unclassified general labor. Here the gas workers' union had in I901 some 45,000 members and other unions brought the total to II 5,000. In all other industries a comparison is without exception in favor of the United States.

To sum up in a word, the British unions are on the whole as important a factor in British industry as the American unions are in the United States, but in Great Britain, with the exception of the textile industry and the general laborers, it is almost exclusively the skilled that are organized, whereas in the United States a very large majority of the total number of unionists are engaged at relatively unskilled work. In Great Britain the movement is divided both in the country at large and within the trades. In America the unity within the trades and industries is almost complete and a national unity seems to be not far distant, while already three-fourths of the unions are affiliated with the great national organization, the American Federation of Labor. Finally, the unions of the United States are growing with a startling rapidity and the growth does not seem to be a mushroom growth.

But if the American labor organizations are more democratic in their membership and more united in their organization than those of Great Britain, are not the latter richer and therefore better able to hold themselves together in adversity or better provided with the sinews of war? Are they not more solid, more practical, more successful-as measured by financial gains made for themselves or their members? 
The financial resources of the British unions are considerably greater than those of the United States and moreover are increasing rapidly. The total funds of the one hundred principal British unions in 1892 were $£_{1} ; 573,944$, in 1902 they were $£_{4}, 372$, I 78 , a total increase of nearly threefold, and a per capita increase of more than Ioo per cent. The income during the same period increased from $t_{1,462,386}$ to $\left\{2,067,666\right.$, remaining near $35^{s}$. or about $\$ 8.50$ per capita.

But what are these vast funds of the British unions? Do they constitute a war-chest, like Russia's famous hoard of gold? Can they all be used as a fund for obtaining more wages and shorter hours? By no means. As far as the union rules and legal regulations are concerned, yes, but from the standpoint of dollars and cents, no. The trade unions of Great Britain, and to a lesser extent those of America, lead a double life. They are labor organizations in the first instance, but they are also insurance companies in their principal functions, very similar to many mutual benefit societies and the industrial insurance companies of the United States. The funds though convertible to trade union uses, both by the union rule and legal right, are for the most part morally and practically pledged to be paid out in benefits.

For the ten years from 1892 to I9OI inclusive, the amounts paid by the British unions in death, sickness, unemployed and other benefits averaged 60.8 per cent. of the total expenditures, while the proportion expended on "disputes" or strikes averaged less than one-third as much or 19.4 per cent., the remainder going to working and miscellaneous expenses. The proportion varied greatly, of course. In I 893 the coal strike brought the "dispute pay" to nearly one-third the total expended and in the great "engineering dispute" it even reached 33.5 per cent. On the other hand, only I2.3 per cent. was expended on dispute pay in I9OI, I0.2 in 1900 and 9.4 in I899. In recent years while about one-tenth of the union income was going directly into the labor conflict, nearly two-thirds $(64.8,65.4$ and 65.2 per cent.) was going for insurance features. And this was not too nuch, for the risks carried by the British unions steadily grow worse as their average membership grows older and their liabilities steadily increase.

The contrast with the American unions is striking. While death benefits are as prevalent here as there, all other forms of benefits are 
less general. Three-fourths of the British unions have sick, accident and out of work benefits. Only one-third of the unions of the American Federation of Labor have sick or accident benefits on a national scale and only one-fourth have out-of-work or travelling benefits. Over a fourth of the British unions have old age benefits practically none in the United States. The amounts paid by the unions of the American Federation of Labor are shown in the following table. The important unions outside the federation are those of the railways and the metalliferous mines, the bricklayers, the masons, the stonecutters and the plasterers, with a total membership of less than half a million men.

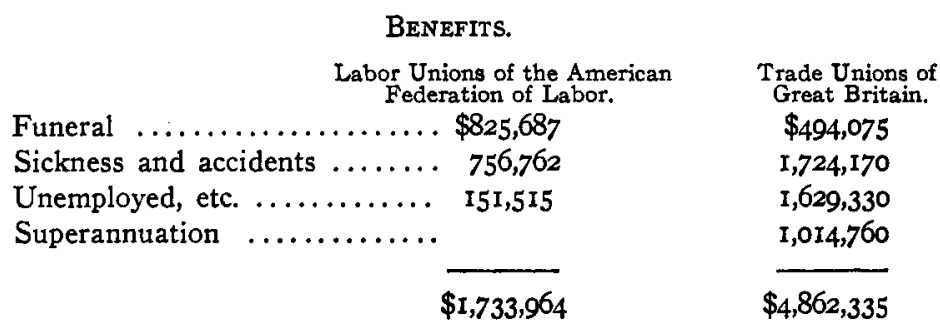

If the unions outside the federation are added, the result would be materially changed. The Order of Railway Conductors, perhaps the smallest of the four big railway unions, paid last year $\$ 835,500$ more than all the unions of the federation expended on death benefits. The four big railway unions alone have expended about twice the total amount recorded by the American Federation of Labor unions. But they are in every way exceptional and more like the British organizations.

Not only are the railway unions exceptional as to their benefit policy, but so also are several unions within the Federation-especially the cigarmakers and the iron moulders. If we subtract the amounts they paid, $\$ 379,000$ and $\$ 260,093$, respectively, from the total above mentioned for the American Federation of Labor, it is reduced by fully one-third-from $\$ 1,733,964$ to $\$ 1,093,87 \mathrm{I}$. But the membership of the Cigarmakers Union was only 40,500 , that of the Moulders 30,000 , both of them together less than one-twentieth of that of the federation. The membership of the four largest railway unions, trainmen, firemen, engineers and conductors is about 200,000 . If we add to the unions just mentioned all others that have import- 
ant benefit features, the plumbers, the barbers, the glass workers, the boot and shoe workers, and all those that are expending more than $\$ 2.00$ per capita on benefits, we find that probably less than half a million of the two and a half million members of the trade unions in the United States are members of organizations that have established such a benefit on a national scale. In Great Britain all the great classes of the unions are paying $\$ 2.00$ or more per capita. All the unions except those of general labor and transport and those of the mining and textile industries are paying benefits of from $\$ 4.00$ to nearly $\$ 8.00$ per capita.

The prevailing custom of the American unions toward benefits is then to leave them to the local unions or to ignore them entirely. In either case the absence of a large national treasury does not necessarily indicate that the workmen do not secure benefits. They may secure them from the industrial insurance companies, so rapidly developing in the United States, or from their local unions. What it does indicate is that the workingmen's insurance and their organization for the economic power and advancement have become two fairly separate and distinct functions in the United States.

The benefit feature is better adapted to British "trade" unionism than to the labor unionism of the United States. In the form of payment and character of the benefit, each "trade" union of course varies, adapting itself to the needs of its members. Once instituted, the benefit therefore becomes a retarding force. But the changing conditions of industry require new classes of members to enforce a successful industrial policy. The specialized benefits check the accession of these new members and so keep the trades apart. The large benefit funds being convertible to immediate use in the form of employment or dispute pay, form a vested interest of the older members that urges them to keep out the new. Many members are not unionists at all at heart, but mere policy holders of "trade" insurance.

But above all, the benefits do not compose a defense.(or aggression) fund. Instead of aiding in the conduct of strikes they hinder their declaration except in those extreme cases where a man is willing not only to sacrifice himself and his family in the present for the cause, but also to give up his long hoarded protection against sickness, accident, unemployment and old age in the future, and finally to sacrifice to a certain degree his wife and children after he is dead. 
As a consequence the American unions are spending twice as much per capita on strikes, to say nothing of the much greater sums drawn by individual workmen in this country from their savings in times of strikes. The sum lost in wages in strikes averaged sixteen times as much as that spent by the unions during the same conflicts during the last census decade.

For the decade from 1892 to 1901 the British unions spent an average of $£ 919,901$ per annum on benefits and only $£ 293,55^{2}$ on strikes. For the decade from I89I to I 900 inclusive, the American unions expended an average of $\$ 831,833$ per annum on strikes, while their average membership in this period was less than half as great. Lately this expenditure has increased rapidly. In I900 it was $\$ 1,434,45^{2}$, while for Great Britain it was for the one hundred principal unions $\operatorname{fI}_{50,283}$. But in 1902 the unions of the American Federation of Labor alone spent $\$ 2,729,604$ on strikes, in 1903, $\$ 2,932,417$, and in $1904, \$ 2,864,642$. If we add to these sums those expended by the bricklayers, the plasterers, the stonecutters and the Western Federation of Miners, we may have half a million or a million more for each of these years. The sum expended by the hundred principal unions of Great Britain in 1893, the year of the coal strike, was $E_{5} 88,373$; in 1897 , the year of the engineering strike, f633,379. The American unions are then expending steadily on strikes a larger amount than that paid out in Great Britain in the largest strike of its history.

Eight years have elapsed since the great engineering dispute in I 897, and since that time there has been no great national contest in the United Kingdom. The amount expended by the unions on attack or defense has fallen to a bare million dollars a year, less than a third of that expended in the United States. The funds have gone on accumulating. The amount per capita doubled from 1892 to I90I, but it is still the trifing sum of 7 Is. 8d. per capita, scarcely $\$ 18.00$, a sum hardly sufficient to cover the liabilities of the unions as insurance institutions, to say nothing of their availability to carry on great labor conflicts.

During the decade for which we have figures (I89I-I900), the one hundred principal unions of Great Britain expended an average annual amount on dispute pay of $£ 293,475$. As the average membership was over a million, the amount paid for strike was hardly $6 \mathrm{~s}$. or $\$ 1.50$ per nember per year. For three years the unions of the [738] 
Federation of Labor, composed in considerable part of unskilled and women workers, have averaged half as much again.

As organizations for collective bargaining the British unions are not expending more, but less for each member than those of the United States. And while the years 1893 and 1897 saw the high water mark of the expenditure of British unions on strikes, the years 1902, 1903 and I904, during which the membership of the Britsh unions has stood still and their strike expenditure fallen as measured by the previous decade, have witnessed not only a rapidly growing membership of the unions of the United States, but an increasing expenditure for each member of the industrial conflict.

As measured either by membership or by financial power, the trade unions of Great Britain, as organizations bettering the economic condition of the working class or increasing its power in the industrial world, seem already inferior to those of the United States. Manifestly under these conditions the American unions are not going to follow in the footsteps of their predecessors, but will develop as they are developing a form of organization, a method of fighting employers, a policy toward the public and an ultimate goal of their own. They have passed out of the stage where they must look to the rest of the world for precedents and the time is coming when the rest of the world must rather look to them. 